\title{
MENGEMBANGKAN SIKAP TOLERANSI DAN KEBERSAMAAN DI KALANGAN SISWA
}

\author{
Oleh: Busri Endang ${ }^{1}$
}

\begin{abstract}
Abstrak
Toleransi sesungguhnya berkembang dalam kerangka adanya keberagaman dalam berbagai dimensi kehidupan, sehingga akan dapat terwujud keserasian dan keharmonisan hidup, jauh dari konflik-konflik dan ketegangan-ketegangan sosial, lebihlebih lagi pertentangan dan permusuhan antar sesamanya dalam masyarakat. Tulisan ini bertujuan mendeskripsikan pentingya pengembangan sikap toleransi dan kebersamaan melalui rekayasa paedagogis guru dalam latar masyarakat majemuk. Kamajemukan ini juga terjadi dalam seting atau lingkungan sekolah, di mana di dalamnya siswa saling berinteraksi, saling belajar menghargai perbedaan serta saling menerima sesuatu karakteristik tertentu yang mungkin pada lingkungannya tidak pernah dia temui.
\end{abstract}

\section{Kata-kata Kunci: Rekayasa Paedagogis Guru, Sikap Toleransi, Kebersamaan}

\section{A. Pendahuluan}

Perubahan-perubahan yang terjadi dalam berbagai aspek kehidupan sebagai dampak langsung atau tidak langsung dari kemajuan ilmu pengetahuan dan teknologi telah merasuk ke dalam berbagai sisi kehidupan individu dan masyarakat. Dampak dari suatu perubahan tersebut disadari atau tidak disadari seringkali juga menyebabkan terjadinya pengikisan nilai-nilai positif dalam kehidupan individu dan masyarakat bilamana tidak diiringi dengan upaya-upaya yang sungguhsungguh dan sistematis untuk mempertahankannya.

Salah satu bentuk nilai positif yang sangat rentan terhadap pengaruh-pengaruh nilai-nilai luar adalah nilai-nilai toleransi dan kebersamaan. Hampir tidak ada pihak yang tidak sependapaat bahwa nilai-nilai ini merupakan kristalisasi dari budaya bangsa yang telah tumbuh berkembang dalam kehidupan masyarakat Indonesia selama

${ }^{1}$ Busri Endang adalah dosen Jurusan Ilmu Pendidikan FKIP-UNTAN Pontianak 
berabad-abad lamanya. Dan tidak ada juga pihak mempertentangkan besarnya manfaat pengembangan nilai-nilai ini dalam kehidupan individu, masyarakat dan berbangsa. Namun arus modernisasi yang seringkali secara gegabah dinilai sebagai sesuatu yang lebih baik semakin menggeser nilai-nilai yang sangat luhur ini. Dampaknya kepentingan menjadi terkotak-kotak dalam bentuk berkembangnya individualisme, kepentingan kelompok yang dominan, kepentingan daerah, kepentingan suku, agama dan berbagai kepentingan-kepentingan dalam sub-sub yang lebih kecil. Lebih jauh persatuan dan kesatuan menjadi pudar, kebersamaan menjadi sesuatu yang tidak memiliki nilai yang diagungkan lagi. Dalam keadaan ini konflik tidak bisa dihindari, bahkan cenderung semakin meluas dan melebar dalam berbagai bentuknya.

Perubahan adalah suatu keharusan, karena diinginkan atau tidak diinginkan perubahan itu mutlak terjadi. Oleh sebab itu perubahan sosial dan masyarakat yang diharapkan adalah perubahan yang sekecil mungkin mengandung resiko munculnya pertikaian, konflik-konflik sosial serta berbagai bentuk gejolak dalam masyarakat (Soedomo, 1990:18). Oleh sebab itu pada waktu bersamaan, perubahan di satu sisi dan upaya pelestarian nilai-nilai positif yang mengarah pada tumbuhnya sikap toleransi dan kebersamaan pada sisi yang lain harus dilakukan.

Upaya untuk mengembangkan nilai-nilai toleransi harus dilakukan dalam berbagai aktivitas dan lingkungan. Dalam lingkungan masyarakat hal ini menjadi sangat penting, karena demikian banyak kepentingan yang terdapat di dalamnya. Benturan-abenturan akan terjadi bilamana tidak adanya saling pengertian serta kebersamaan. Filosof Isaiah Berlin seperti diungkapkan Tilaar, (1999: 160) mengemukakan bahwa yang diperlukan dalam masyarakat bukan sekedar mencari kesamaan dan kesepakatan yang tidak mudah untuk dicapai. Justru yang paling penting di dalam masyarakat yang berbhinneka adalah adanya saling pengertian.

Dalam lingkungan sekolah sikap toleransi dan kebersamaan menjadi salah satu filar yang penting dan mendasar untuk dikembangkan. Sekolah disepakati sebagai bentuk sistem sosial yang di dalamnya terdiri dari komponen-komponen masyarakat sekolah dengan berbagai latar; ekonomi, lingkungan keluarga, kebiasaan-kebiasaan, agama bahkan keinginan, cita-cita dan minat yang berbeda. Dengan perbedaanperbedaan ini tidak mustahil dalam masyarakat sekolah terjadi benturanbenturan kepentingan yang juga dapat mengarahkan kepada konflikkonflik kepentingan, dan oleh sebab itu perlu upaya-upaya yang secara sengaja dan terus menerus diarahkan untuk mengembangkan toleransi dan kebersamaan ini. 
Upaya-upaya untuk mengembangkan sikap toleransi dapat dilakukan melalui rekayasa kegiatan pembelajaran di kelas maupun latihan-latihan praktis dalam kehidupan nyata di luar kelas. Berkaitan dengan aspek ini GBHN (1999: 12) memberikan arahan dan kritik tentang pengembangan sikap, watak atau kepribadian ini dalam ungkapan bahwa;

"Di dalam bidang pendidikan masalah yang dihadapi adalah berlangsungnya pendidikan yang kurang bermakna bagi pengembangan pribadi dan watak peserta didik, yang berakibat hilangnya kepribadian dan kesadaran akan makna hakiki kehidupan. Mata pelajaran yang berorientasi akhlak dan moralitas dan agama kurang diberikan dalam bentuk latihan-latihan pengamalan untuk menjadi corak kehidupan seharihari. Karenanya masyarakat cenderung tidak memiliki kepekaan yang cukup untuk membangun toleransi, kebersamaan, khususnya dengan menyadari keberadaan masyarakat yang majemuk.

Berdasarkan beberapa pertimbangan di atas, maka diperlukan keinginan yang kuat bagi setiap pendidik untuk secara terus menerus berupaya mengembangkan sikap toleransi dan kebersamaan ini kepada siswa, sehingga mereka mendapatkan latihan-latihan dan pengalaman yang bermakna terkait dengan aspek-aspek tersebut, untuk selanjutnya dapat dibawa dan dikembangkan dalam lingkungan masyarakat yang lebih majemuk. Hal ini sangat terkait dengan peran dan fungsi sekolah yang tanggung jawab utamanya adalah untuk membantu siswa mengembangkan kemampuan-kemampuannya, sekaligus mempersiapkan mereka agar mampu beradaptasi, bersosialisasi, bahkan lebih dari itu yaitu menjadi pelopor perubahan kebudayaan. Karena itu masyarakat sekolah harus merupakan masyarakat bermoral, dan secara keseluruhan budaya kampus/sekolah adalah budaya yang bermoral. Hanya dengan demikian lembaga ini dapat menjadi pelopor dari perubahan kebudayaan secarta total yaitu bukan hanya nilai-nilai ilmu pengetahuan dan teknologi, tetapi juga tempat persemaian dari pengembangan nilai-nilai moral kemanusiaan (Tilaar: 1999: 76).

Tanggung jawab kearah upaya pengembangan nilai-nilai toleransi pada siswa harus dirasakan sebagai tanggung jawab bersama seluruh pendidik yang ada di sekolah. Namun demikian secara ekplisit upayaupaya yang lebih sistematis dan terencana harus menjadi bagian yang utuh dari kegiatan pembelajaran khususnya pada mata pelajaran-mata pelajaran yang memiliki kadar lebih besar dalam pembinaan sikap dan kepribadian siswa. Karena itu guru secara sengaja perlu mengembangkan dan merancang model-model pembelajaran yang diyakini mampu mengembangkan nilai-nilai positif ini kepada siswa. Upaya-upaya yang 
sengaja dan sistematis seperti ini sangat diperlukan, karena dalam pendidikan sekolah peranan guru sampai saat ini masih menempati kedudukan yang utama, lebih-lebih lagi dalam proses pembalajaran nilai dan moral.

\section{B. Sikap Toleransi dan Kebersamaan Serta Model-model Pembelajaran}

\section{Pengertian}

Toleransi sesungguhnya berkembang dalam kerangka adanya keberagaman, utamanya adalah keberagaman agama dan budaya termasuk di dalamnya kebiasaan-kebiasaan, tradisi atau adat istiadat yang menyertainya. Oleh sebab itu semakin besar keberagaman suatu bangsa atau suatu masyarakat, maka akan semakin besar pula tuntutan bagi keharusan pengembangan nilai-nilai toleransi dalam kehidupan masyarakat dan individu, sehingga akan dapat terwujud keserasian dan keharmonisan hidup, jauh dari konflik-konflik dan keteganganketegangan sosial, lebih-lebih lagi pertentangan dan permusuhan antar sesamanya dalam masyarakat.

Dalam pengertian yang luas toleransi lebih terarah pada pemberian tempat yang luas bagi keberagaman dan perbedaan yang ada pada individu atau kelompok-kelompok lain. Oleh sebab itu pada awal pembahasan ini perlu penekanan kembali bahwa tidak benar bilamana toleransi dimaknai sebagai pengebirian hak-hak individu atau kelompok tertentu untuk disesuaikan dengan kondisi atau keadaan orang atau kelompok lain, atau sebaliknya mengorbankan hak-hak orang lain untuk dialihkan sesuai dengan keadaan atau kondisi kelompok tertentu. Toleransi justru sangat menghargai dan menghormati perbedaanperbedaan yang ada pada masing-masing individu atau kelompok tersebut, namun di dalamnya diikat dan disatukan dalam kerangka kebersamaan untuk kepentingan yang sama. Toleransi adalah penghormatan, penerimaan dan penghargaan tentang keragaman yang kaya akan kebudayaan dunia kita, bentuk ekspresi kita dan tata cara sebagai manusia. Hal itu dipelihara oleh pengetahuan, keterbukaan, komunikasi, dan kebebasan pemikiran, katahati dan kepercayaan. Toleransi adalah harmoni dalam perbedaan (UNESCO APNIEVE, 2000: 54)

Penghormatan terhadap keragaman mengandung pengertian bahwa setiap orang dituntut untuk mampu melihat perbedaan yang ada pada orang lain atau kelompok lain sebagai sesuatu yang tidak harus dipertentangkan dengan apa yang ia miliki. Sesuatu karakteristik yang 
berbeda pada orang lain tersebut hendaknya dipandang sebagai bagian yang memberikan kontribusi bagi semakin kaya dan luasnya kebiasaan dan budaya secara keseluruhan. Ini berarti bahwa di dalam perbedaanperbedaan yang ada sesungguhnya memiliki nilai manfaat bilamana dapat digali dan dipahami dengan kerafian. Selama ini terkesan bahwa keberagaman sebagian kita tidak sejalan dengan sifat-sifat Allah, padahal salah satu defenisi keberagaman yang tertua dan masih relevan hingga kini adalah defenisi Sneca (455M) yang menyatakan bahwa keberagaman adalah upaya meneladani Tuhan dalam sifat-sifat-Nya (Sihab, 2001: 21). Dalam Al-Quran dinyatakan:

Untuk tiap-tiap umat di antara kamu, Kami berikan aturan dan jalan yang terang. Sekiranya Allah menghendaki, niscaya kamu dijadikan-Nya satu umat (saja), tetapi Allah hendak menguji kamu terhadap pemberian-Nya kepadamu, maka berlomba-lombalah berbuat kebajikan (Q.S Al-Maidah 5: 48)

Penegasan terhadap makna toleransi dalam kehidupan masyarakat, termasuk dalam lingkungan sekolah sebagai salah satu bentuk dari suatu sistem sosial menjadi pentingya adanya, sebab jangan sampai terjadi penolakan terhadap nilai-nilai toleransi hanya dikernakan individu atau kelompok merasa cemas dan hawatir bahwa dengan toleransi itu menjadi bentuk perendahan diri dan pemujaan terhadap orang lain. Toleransi bukanlah pemberian, perendahan diri, atau pemanjaan. Toleransi terutama adalah suatu sikap yang aktif didorong oleh pengakuan atas hak-hak asasi manusia universal dan kebebasan-kebebasan fundamental orang-orang lain. Hal itu tidak boleh dalam keadaan bagaimana pun dipergunakan untuk membenarkan pelanggaran nilai-nilai fundamental ini. Toleransi adalah untuk dilaksanakan oleh orang-seorang, kelompok-kelompok dan Negara-negara. (UNESCO APNIEVE, 2000: 54)

Dalam lingkungan sekolah sebagaimana halnya dengan lingkungan masyarakat, juga memiliki banyak keberagaman terutama berkenaan dengan kehidupan dan aktivitas siswa. Siswa pada suatu sekolah cenderung membawa atau sekurang-kurangnya banyak dipengaruhi oleh lingkungan keluarga dalam berbagai bentuk kebiasaankebiasannya serta lingkungan masyarakat dengan latar budayanya, dan sudah barang tentu dipengaruhi pula oleh nilai-nilai agama yang mereka anut. Kesemuanya ini akan tercermin dalam bentuk sikap dan prilaku sehari-hari di sekolah. Oleh sebab itu di kalangan siswa juga sangat penting dikembangkan nilai-nilai toleransi, agar mereka dapat menghormati dan menerima perbedaan-perbedaan orang lain, dapat 
menghargai kebebasan-kebebasan fundamental siswa lainnya, tanpa perendahan diri apalagi menghilangkan hak-hak individu dirinya. Dari pendapat-pendapat terdahulu dapat dikemukakan bahwa toleransi di kalangan siswa diartikan sebagai penghormatan, penerimaan dan penghargaan tentang keragaman kebiasaan-kebiasaan, budaya serta perbedaan kemampuan siswa-siswa dan unsur-unsur lain yang ada di lingkungan sekolah dalam upaya terciptanya kebersamaan dan keharmonisan bersama.

\section{Tanggung Jawab Sekolah DalamPengembangan Sikap Toleransi Siswa}

Sebagaimana telah dijelaskan sebelumnya bahwa sekolah adalah merupakan suatu sistem sosial masyarakat, di mana para siswa saling belajar untuk berinteraski, belajar memahami norma-norma sosial sekolah, belajar bekerjasama, belajar menghargai dan belajar berbagai aspek kehidupan sebagaimana layaknya dalam masyarakat. Hal ini beranjak dari suatu filosofi bahwa setiap anak dikaruniai benih untuk bergaul, bahwa setiap orang dapat saling berkomunikasi yang pada hakekatnya di dalamnya terkandung unsur saling memberi dan menerima (Tirtarahardja: 1994: 18). Proses belajar yang dilakukan terhadap berbagai aspek kehidupan dalam lingkungan sekolah ini akan menjadi bekal bagi siswa untuk lebih siap memasuki lingkungan masyarakat, terutama sekali setelah menamatkan pendidikan pada jenjang tertentu.

Khusus berkaitan dengan pengembangan nilai-nilai toleransi dan kebersamaan, lembaga pendidikan sekolah merupakan wahana yang paling tepat untuk melatih dan sekaligus menerapkan nilai-nilai ini. Hal ini utamanya disebabkan di dalam lingkungan sekolah siswa memiliki latar belakang yang sangat beragam, baik agama, susku, latar sosial ekonomi, latar pendidikan orang tua, daerah termasuk adat adat istiadat dan budaya. Dalam kondisi keberagaman ini sudah barang tentu akan ditemukan banyak perbedaan dalam sikap dan prilaku siswa. Sekolah dipandang sebagai wahana yang mempercepat impelementasi dari pluralisme melalui berbagai bentuk kegiatan seperti workshop, latihanlatihan dan kegiatan-kegiatan dalam kelompok kecil (Joan T, 1992: 5). Perbedaan-perbedaan inilah yang harus dipahami dan bahkan saling dihormati, sehingga memungkinkan tumbuhnya solidaritas dan kebersamaan antar sesama siswa. Menghormati perbedaan tidak berarti menghilangkan identitas diri, karena menghormati perbedaan sesungguhnya adalah memberikan peluuang dan kesempatan kepada orang lain untuk melakukan sesuatu sesuai dengan karakteristik dirinya. 
Contoh untuk ini adalah bagaimana seorang siswa harus belajar menghormati ketika temannya harus melaksanakan ibadah, menghormati dan memberi kesempatan tatatkala temannya harus melaksanakan tugastugas tertentu, atau mungkin memberikan menghormati perbedaanperbedaan prilaku dalam koridor yang tidak bertentangan norma-norma umum sekolah. Pendidikan adalah alat yang paling mangkus untuk menghindari nirtoleransi. Langkah pertama dalam pendidikan toleransi adalah mengajar orang-orang tentang hak-hak dan kebebasan-kebebasan bersama (berbagi) mereka, sehingga dapat dihormati, dan mengembangkan kemauan untuk melindungi hak-hak dan kebebasankebebasan orang lain (UNESCO APNIEVE, 2000: 156).

Tujuan pengembangan sikap toleransi di kalangan siswa di sekolah, di samping wahana latihan agar mereka lebih lanjut dapat menerapkan dan mengembangkankannya secara luas dalam kehidupan masyarakat, juga didasari pemikiran bahwa lembaga pendidikan sekolah secara fundamental memang memiliki tanggung jawab secara komprehensip terhadap pembentukan intelektual dan kepribadian siswa secara utuh. Durkheim mengemukakan bahwa tiap-tiap guru harus mampu mengembangkan cita-cita moral yang ada di balik sistem aturan yang telah dikembangkan, dan memberi peluang kepada generasi mendatang untuk memenuhi tuntutan-tuntutan validitas yang baru (Haricahyono, 1995: 203)

Toleransi diperlukan antara orang seorang dan pada tingkattingkat keluarga dan paguyuban. Promosi toleransi dan pembentukan sikap-sikap keterbukaan, saling mendengar dan solidaritas hendaklah mengambil tempat di sekolah dan perguruan tinggi dan melalui pendidikan luar sekolah, di rumah dan di tempat kerja (UNESCO APNIEVE, 2000: 155). Pandangan yang sempit melihat peran sekolah lebih kepada pengembangan intelektual siswa, sementara aspek-aspek kepribadian utamanya menjadi tanggung jawab keluarga/orang tua. Sesungguhnya tidak demikian, karena pendidikan tidak memilah tanggung jawab pembentukan intelektual dan kepri-badian, akan tetapi sudah sangat jelas bahwa kedua aspek ini berada dalam satu kesatuan yang integral yang mempunyai kedudukan sama pentingnya. Bilamana diselusuri selangkah kebelakang dalam pergulatan pendidikan melalui Perguruan Taman Siswa, Ki Hajar Dewantara telah memberikan ketegasannya, sehingga pendidikan Indonesia memang memiliki perbedaan karakteristik dengan sekolah-sekolah di negara-negara Barat.; bahwa jika dibandingkan dengan sistem "sekolah" menurut aliran Barat, maka nampak teranglah bahwa sistim Barat itu semata-mata mementingkan pencaharian ilmu dan 
kecerdesan keduniawian, sedangkan pendidikan di Indonesia teristimewa mementingkan pencaharian ilmu dan kecerdasan budipekerti untuk menjadi manusia yang bahagia (Dewantara, 1977: 474).

\section{Model-model Pembelajaran Untuk Mengembangkan Sikap Toleransi}

Sikap toleransi yang di dalamnya mengandung nilai-nilai penghargaan, rasa hormat terhadap hak-hak dan perbedaan serta keragaman orang lain merupakan bagian dari pendidikan umum, karena menurut R.O. Hand dan D.B. Bidna (dalam Sumaatmadja, 1990: 2) bahwa pendidikan umum juga berkenaan dengan kemampuan mengatur dan menyerasikan sendiri dengan situasi lingkungan, memahami diri sendiri, tenang dan wajar dalam mengatasi situasi yang nyata, berkepribadian wajar. Terkait dengan pendapat tersebut maka terdapat sejumlah model pembelajaran dalam mengembangkan sikap toleransi ini, baik secara formal, informal maupun nonformal.

Dalam pemahaman yang luas pendidikan umum dapat dilaksanakan tiap kesempatan secara informal, nonformal dan formal. Untuk ini maka pendekatan yang dapat diterapkan adalah meliputi pendekatan perorangan (personal approach), pendekatan kelompok (interpersonal approach), dan pendekatan klasikal (classical approach). Metode penyajiannya juga sangat beragam dan luwes melalui cerita, ceramah, permainan simulasi, tanya jawab, diskusi dan tugas mandiri. Singkatnya setiap bentuk sambung rasa (komunikasi) dapat dimanfaatkan dalam proses pendidikan umum (Sumaatmadja, 1990: 9)

Meskipun secara umum model-model pembelajaran untuk mengembangkan sikap toleransi sebagai bagian dari pendidikan umum demikian banyak dan luwes namun terdapat beberapa model yang secara lebih spesifik ditawarkan khususnya untuk bidang pendidikan moral termasuk di dalamnya pengembangan sikap toleransi serta kemampuan berinteraksi sosial. Model-model yang ditawarkan yang menitikberatkan pada interaksi sosial ini ialah pada proses latihan menghayati hakekat nilai/moral melalui proses pelibatan langsung dalam proses-proses simulatif atau situasi sebenarnya (Udin Saripudin, 1989: 136). Dari proses-proses interaksi ini para siswa diharapkan dapat memperoleh wawasan fungsi, peran dan tanggung jawab moral dan sosial yang sesungguhnya dalam masyarakat dan dapat memperkuat pengertiannya tentang konsep dan prinsip nilai dan moral. Beberapa model tersebut adalah: 
a. Model Investigasi Kelompok (Group Investigation);

Model ini bertolak dari pandangan John Dewey (1917), Herbert Tellen (1960) dalam Joyce dan Weil (1986) yang memberikan pernyataan dengan tegas bahwa "pendidikan dalam masyarakat yang demokratis seyogyanya mengajarkan proses demokrasi secara langsung". Atas dasar ini maka model ini menawarkan agar dalam mengembangkan masalah moral dan sosial siswa diorganisasikan dengan cara melakukan penelitian bersama atau "cooperative inquiry" terhadap masalah-masalah sosial dan moral, maupun masalah akademis. Pada dasarnya model ini dirancang untuk membimbing para siswa mendefenisikan masalah, mengekplorasi berbagai cakrawala mengenai masalah itu, mengumpulkan data yang relevan, mengembangkan dan mengetes hipotesis. Dalam rangka itu, para guru seyogyanya mengorganisasikan proses belajar melalui kerja kelompok dan mengarahkannya, membantu para siswa menemukan informasi, dan mengelola terjadinya berbagai interaksi dan aktivitas belajar.

b. Model Bermain Peran (Role Playing);

Model ini dirancang oleh Fanie dan Heorge Shaftel (1984), khususnya untuk membantu siswa memperlajari nilai-nilai sosial dan moral dan pencerminannya dalam prilaku. Di samping itu model ini digunakan pula untuk membantu para siswa mengumpulkan dan mengorganisasikan isu-isu moral dan sosial, mengem-bangkan empathy terhadap orang lain, dan berupaya memperbaiki keterampilan sosial. Dalam model ini siswa dibimbing untuk memecahkan berbagai konflik belajar mengambil peran orang lain, dan mengamati prilaku sosial.

\section{c. Model Penelitian Yurisprudensi (Jurisprodential Inquiry)}

Model ini pada mulanya dirancang dan digunakan untuk para pelajar Sekolah Menengah Pertama dalam mengjarkan ilmu sosial. Pada dasarnya metode ini menerapkan metode studi kasus dalam proses peradilan dan menerapkannya dalam suasana belajar di sekolah. Dalam model ini para pelajar sengaja dilibatkan dalam masalah-masalah sosial yang menuntut pembuatan kebijakan pemerintah yang diperlukan serta berbagai pilihan untuk mengatasai isu tersebut, misalnya tentang konflik moral, nirtoleransi dan sikap-sikap sosial lainnya.

Walaupun model ini semula dan terutama dirancang untuk digunakan dalam pengajaran ilmu sosial, potensial untuk digunakan dalam bidang studi yang membahas isu-isu kebijaksanaan umum atau berkaitan 
dengan kebijaksanaan umum, termasuk yang berkenaan dengan isu-isu atau konpflik moral dalam kehidupan sehari-hari.

\section{d. Model Penelitian Sosial (Social Science Inquiry)}

Model ini dikembangkan atas dasar kerangka konseptual yang sama dengan penelitian ilmiah yang diterapkan dalam bidang ilmu-ilmu alamiah dan model penelitian sosial dalam bidang ilmu-ilmu sosial. Walaupun model-model sosial ini dirancang secara khusus untuk memanfaatkan proses sosial, dapat juga digunakan untuk mencapai tujuan akademis, seperti latihan berfikir dan pembangunan konsep. Dasar dari model ini ialah proses kesepakatan sosial (social negotiation). Model ini menuntut para pelajar untuk menguji dirinya sendiri, prilaku kelompok, dan proses sosial dan etis yang lebih besar.

Pengembangan sikap toleransi dan kebersamaan di kalangan siswa, di samping terkait dengan interaksi dirinya dengan orang lain, juga dengan sendirinya berkaitan pula dengan pengembangan pribadi. Jika dikembalikan kepada postulat pendidikan moral dari Piaget yang juga dipakai oleh Kohlberg (Duska dan Whelan 1997), maka model pembinaan pribadi akan memberi andil besar dalam membina keadaan bahwa prilaku manusia memang terikat oleh norma yang berlaku. Oleh sebab itu harus ditumbuhkan dalam diri siswa, kualitas pribadi, dalam hal ini komitmen pribadi siswa terhadap nilai-nilai moral.

Esensensi tujuan Pendidikan Moral Pancasila yang didukung oleh model-model yang berorientasi pada pembinaan pribadi sesungguhnya adalah "penghayatan dan pengamalan nilai-nilai Pancasila". Dalam kerangka konsep "Confluent taxonomy" (Saripudin, 1989: 139), proses penghayatan dan pengamalan ini tidak terlepas dari proses penalaran. Karena itu penerapan model-model pembinaan pribadi merupakan salah satu sarana bagi terbinanya pribadi siswa yang mencerminkan esensi nilai moral Pancasila.

Beberapa model pembelajaran yang dapat dikembangkan untuk pembinaan kepribadian ini adalah;

a. Model pengajaran tanpa arahan (non Directive Teaching);

Model ini pada prinsipnya adalah meletakkan peranan guru untuk secara aktif membangun kerjasama yang diperlukan dan memberikan bantuan yang dibutuhkan pada saat para pelajar mencoba memecahkan masalah. Model ini digunakan dalam berbagai cara, terutama sebagai model dasar untuk melaksanakan pendidikan secara lkeseluruhan. Kedua, model ini digunakan dengan cara mengkombinasikannya dengan model lain untuk menjamin bahwa hubungan itu dibuat sendiri 
oleh para siswa. Ketiga, model ini digunakan pada saat siswa merencanakan kegiatan mandiri atau kelompok. Keempat, model ini dipakai secara periodik pada saat memberikan penyuluhan kepada para siswa, menemukan apa yang sedang mereka pikirkan dan rasakan, dan membantu mereka memahami apa yang mereka lakukan. Seperti halnya model lain, model ini telah dipergunakan dalam berbagai situasi dan berbagai mata pelajaran, dan secara khusus dirancang untuk mengembangkan "selfunderstanding" dan "independence", karena itu dapat dipakai secara efektif untuk mencapai tujuan yang bersifat sosial dan moral.

b. Model Sinektis (Synectics Models);

Pada mulanya model ini dikembangkan untuk dipakai dalam kelompok kreatif atau "creative group". Model ini dirancang untuk membantu individu membuka pintu pemecahan masalah, kegiatan tulis menulis dan memperoleh pandangan baru dalam berbagai topik. Di kelas model ini diperkenalkan kepada para siswa dalam rangkaian bengkel kerja sampai kepada saat di mana mereka dapat menerapkan prosedur secara individual dalam kelompok yang sedang bekerjasama. Walaupun model ini dirancang untuk memberikan ransangan kreativitas, model ini telah memberikan dampak pengiring berupa dorongan bagi tumbuhnya kerjasama, belajar keterampilan, dan rasa hangat dalam hubungan antar siswa serta memper-kuat nilai sosial.

c. Model Latihan Kesadaran (Awareness Training)

Seperti dikemukakan oleh Saripudin (1989) bahwa menurut beberapa pakar antara lain (Brown, 1964; Perl, 1968; Schiltz, 1958 dan 1967), tujuan model ini adalah memperluas kesadaran diri dan kemampuan untuk merasa dan berpikir adalah tujuan utama dari model ini. Model ini berisikan rangkaian kegiatan lokakarya atau workshop yang dapat mendorong timbulnya refleksi hubungan antar individu, citra diri atau "self immage", ekperimentasi dan penampilan diri.

d. Model pertemuan kelas (Classroom meeting)

William Glaser (1965) mengadaptasi model konseling untuk merancang model ini dengan maksud membantu para pelajar memikul tanggung jawab atas prilakunya dan tanggung jawab untuk lingkungan sosialnya sehingga dapat digunakan dalam lingkungan kelas. Di dalam kelas model ini diwujudkan dalam bentuk rapat atau pertemuan di mana kelompok bertanggung jawab untuk membangun 
sistem sosial yang sesuai untuk melaksanakan tugas-tugas akademis dengan mempertimbangkan unsur perbedaan perseorangan dengan tetap menghargai tugas-tugas bersama dan hak-hak orang lain.

Beberapa model yang dikemukakan di atas dapat dijadikan sebagai alternatif dalam kegiatan pembelajaran, baik mata pelajaran Pendidikan Moral Pancasila maupun mata pelajaran lain terutama yang memiliki muatan lebih besar tentang pengembangan nilai dan moral, seperti pelajaran Pendidikan Agama, mata pelajaran Ilmu Pengetahuan Sosial. Bahwa dalam semua nilai dan situasi pendidikan tutnutan akan kebebasan yang secara potensial bisa menentukan pribadi-pribadi yang otonom dan sadar diri harus memperoleh perhatian istimewa (Keller \& Reuss, 1985). Dalam prase yang lebih praktis bahwa apapun yang kita kerjakan dalam pendidikan moral anak harus belajar mengembangkan cara pandang personalnya, dan pada saat yang sama mempertimbangkan pula cara pandang orang lain.

\section{Rekayasa Pembelajaran Untuk Mengembangkan Sikap Toleransi dan Kebersamaan}

Pengembangan sikap sikap toleransi dan kebersamaan di kalangan siswa harus diletakkan sebagai salah satu bagian mendasar dalam proses pendidikan dan pembelajaran di sekolah. Upaya ini tidak terbatas atau hanya menjadi tanggung jawab guru bidang studi tertentu, misalnya hanya merupakan tanggung jawab guru Pendidikan Pancasila dan Kewarganegaraan atau guru Pendidikan Agama, akan tetatpi seluruh guru, bahkan personalia non gurupun yang ada di sekolah mempunyai tanggung untuk mengembangkan sikap ini. Meskipun demikian dapat diakui dan dibenarkan bahwa tanggung jawab lebih besar khususnya dalam proses pembelajaran tentu pada guru yang menangani mata pelajaran-mata pelajaran yang lebih banyak bermuatan nilai dan moral.

Dalam proses pembelajaran bagi upaya pengembangan sikap toleransi dan kebersamaan ini, guru menempati kedudukan yang sangat penting karena bagai-mana berlangsungnya proses pembelajaran itu lebih banyak diwarnai oleh rancangan program pembelajaran yang dilakukan atau dibuat oleh guru. Bilamana model-model program pembelajaran yang dirancang guru hanya memiliki nuansa pengembangan kognitif, maka yang akan terjadi adalah proses pembelajaran yang mengarah pada penguasaan pengetahuan. Demikian pula halnya bilamana model pembelajaran yang dipilih oleh guru mengasrah pada pengembangan aspek-aspek afektif dan psikomotorik maka proses pembelajaran yang terjadi akan lebih terarah pada pengembangan aspek-aspek ini. Oleh 
karena itu rancangan program pembelajaran yang direkayasa atau dibuat oleh guru akan sangat mewarnai iklim belajar dan peroleh hasil belajar siswa.

Agar sikap toleransi dan kebersamaan dapat dikembangakan di kalangan siswa, maka guru hendaknya dapat merancang kegiatan belajar yang mengarah pada pengembangan sikap tersebut. Model-model pembelajaran yang dikemukakan pada bagian terdahulu dapat menjAdi alaternatif untuk mengembangkan nilai-nilai, termasuk pengembangan sikap toleransi dan kebersamaan ini. Model-model tersebut adalah model teoritik yang sudah barang tentu harus dikembangkan lebih lanjut oleh guru sesuai dengan karakteristik mata pelajaran, siswa, waktu belajar, lingkungan kelas dan termasuk kemampuan guru dalam menerapkan atau mengembangkannya. Sebagai ilustrasi dan contoh adalah ketika guru akan mengembangkan Model Investigasi Kelompok (Group Investigation) dalam proses pembelajaran Pendidikan Pancasila dan kewarganegaraan. Seperti telah dijelaskan bahwa model ini pada intinya adalah dimana siswa diorganisasikan dengan cara melakukan penelitian bersama atau "cooperative inquiry" terhadap masalah-masalah sosial dan moral, maupun masalah akademis. Oleh sebab itu bilamana model ini yang akan diterapkan, maka terlebih dahulu guru harus merancang pembelajaran yang sekurang-kurang mencakup beberapa hal; (1) berapa jumlah kelompok siswa, (2) berapa orang tiap-tiap kelompok, (3) fenomena/aspek apa yang akan diteliti, dan bagaimana melakukannya, (4) kapan waktu melakukan dan berapa banyak waktu yang diperlukan untuk itu, (5) bagaimana menganalisis hasil temuannya, (6) bagaimana melaporkan atau menyajikannya, serta (7) bagaimana mengevaluasi. Kesemuanya ini akan memrlukan rancangan dan persiapan yang harus jelas dan spesisfik sehingga waktu dapat dipergunakan dengan sebaik-baiknya.

Bilamana model tersebut di atas digunakan untuk mengembangkan sikap toleransi dan kebersamaan siswa, maka aspek kehidupan sosial/masyarakat yang menjadi sasaran penelitian siswa adalah yang berkaiatan dengan fenemone-fenomena tersebut. Misalnya mengamati suasana ketika dilaksanakan kerja bakti di lingkungan tempat tinggal siswa, suasana tatakala umat tertentu melaksanakan ibadah, suasana ketika ada pertemuan/rapat di lingkungan siswa, suasana di jalan raya, di tempat-tempat umum atau kehidupan anggota-anggota masyarakat sehari-hari di lingkungan siswa tinggal. Aspek-aspek nayata dari prrilaku kehidupan masyarakat ini merupakan relatitas yang mungkin oleh siswa sehari-hari selama ini tidak menjadi sesuatu yang sengaja teramati. Dengan penerapan model ini siswa sengaja dibawa untuk melihat secara 
nyata prilaku-prilaku masyarakat yang berkaitan dengan nilai-nilai toleransi dan kebersamaan ini. Mungkin selama ini oleh siswa fgenomenafenomena tersebut tidak menarik dan bahkan mungkin tidak bearti, akan tetapi ketika secara sengaja diamati dan dianalisis justru akan menjadi sesuatu yang menarik dan berharga yang mengandung banyak pelajaran.

Dari apa yang diamati siswa selanjutnya dianalisis, mungkin dalam pengertian yang sangat sederhana di mana siswa memberikan komentar-komentar secara bebas tentang apa yang mereka lihat/amati. Analisis siswa ini merupakan analisis nilai, di mana siswa sudah mulai dapat membedakan mana sikap yang menunjukkan toleransi dan mengandung nilai-nilai kebersamaan, mana sikap nirtoleransi yang memiliki bobot sangat kecil pada nilai-nilai kebersamaan. Penerapan model ini dalam pembelajaran sekaligus mengajarkan siswa menggunakan pendekatan-pendekatan yang lebih sistematik dan ilmiah dalam pengumpulan dan analisis data sehingga mereka dapat menemukan nilainilai pribadi mereka sendiri dan nilai-nilai sosial di mana mereka hidup dan pada gilirannya mereka mampu membuat pertimabnagn-pertimbangan serta keputusan nilai yang rasional dan dapat dipertahankan. Penekanan model ini diletakkan pada pengumpulan dan analisis informasi serta menetapkan mana yang fakta, mana yang bisa dipandang sebagai pendapat, asumsi, kriteria, propaganda atau informasi yang salah. Bilamana siswa berhadapan dengan konflik nilai siswa akan dapat membedakan antara apa yang mereka ketahui sebagai fakta (bukti), apa yang mereka duga tetapi tidak dapat mereka buktikan yang berarti merupakan pendapat (opini atau perkiraan). Melalui proses evaluasi dan penalaran logis siswa mencapai keputusan berdasar serangkaian pertimbangan nilai yang diperoleh secara rasional dan mencapai prinsipprinsip nilai.

Upaya-upaya untuk melibatkan siswa dalam kehidupan nyata akan mem-berikan nuansa pendidikan lebih pentingamakna lebih besar dibandingkan dibandingkan bilamana mereka hanya mendengar atau mengetahui secara verbalistik dari guru. Di samping itu dalam suasana yang demokratis selayaknya siswa memang harus lebih banyak diberikan kesempatan secara terbuka untuk mengetahui secara langsung berbagai peristiwa, berbagai fenomena prilaku masyarakat. Sebagaaimana diungkapkan sebelumnya bahwa pendidikan dalam masyarakat demokratis seyogyanya mengajarkan demokrasi secara langsung. Karena itu pendidikan untuk para siswa, anak-anak muda pada umumnya disarankan untuk lebih banyak diarahkan pada model-model pembelajaran 
yang mengorganisasikan siswa pada berbagai bentuk penelitian bersama terhadap masalah-masalah sosial dan moral.

Keterlibatan siswa dalam berbagai bentuk penelitian bersama terhadap gejala-gejala sosial di samping diyakini mampu mempertajam penalaran dan kepekekaan siswa pada terhadap nilai-nilai moral termasuk menumbuhkembangkan sikap toleransi, juga akan menjadai wahana yang dapat mempererat kebersamaan sesama siswa di dalam kelompoknya. Banks (1997: 94) mengungkapkan bahwa sejumlah penelitian yang dilakukan sejak tahun 1970 berkaitan dengan belajar bersama dan hubungan interrrasial (Cooperative Learning and interracial contact), antara lain diari hasil penelitian Slavin (1985), mengemukakan bahwa dengan belajar bersama dan membina hubungan interasial akan mampu menumbuhkan motivasi dan harga diri siswa. Penelitian yang dilakukan oleh Aroson \& Bridgement (1979) menyebutkan bahwa pendekatan pembelajaran tersebut di atas telah berhasil membantu siswa untuk mengembangkan rasa emphati mereka.

Pembelajaran pendidikan nilai, khususnya upaya pengembangan sikap toleransi dan kebersamaan pada siswa secara umum sesungguhnya tidak banyak berbeda dengan kegiatan belajar pada umumnya, namun dalam pembelajaran nilai unsur pemanfaatan indra dan unsur-unsur keaktifan sangat penting kedudukannya. Suatu hal yang harus digarisbawahi bahwa tujuan pendidikan kognitif maupun moral tidak hanya membantu siswa mempelajari dan memahami secara rasional dan mengarahkan prilakunya kecara-cara yang makin baik yang secara internal dilakukan secara konsisten dan diinginkan masyarakat. Pengajaran harus dipandang dan diletakkan sebagai wahana untuk membantu siswa berpikir secara rasional, kritis dan kreatif, mampu membuat pertimbangan yang matang, memiliki pandangan yang luas dan akhirnya mampu membuat keputusan-keputusan yang bertanggung jawab. Karena itu siswa harus mendapatkan kesempatan untuk bekerja lebih dari sekedar 'mendengarkan', dan berpikir tentang informasi. Mereka harus secara aktif berpartisipasi dalam proses belajar mereka. Kesemuanya itu menyiratkan betapa penting kedudukan guru terutama dalam merancang kegiatan-kegiatan pembelajaran yang mengarah pada pelibatan siswa secara lebih komprehensip.

Dari semuanya ini bahwa penentuan model-model pembelajaran yang akan diplih oleh guru sesungguhnya bukan menjadi persoalan utama, karena gurulah yang lebih mengetahui bagaimana kesesuaian dan ketetapannya dengan kondisi yang dihadapi. Sesuatu yang sangat penting yang perlu dikemukakan bahwa rekayasa pembelajaran guru akan sangat 
mewarnai proses pembelajaran yang berlangsung dan hasil belajar yang akan diperoleh. Sejumlah pendapat para ahli dan sejumlah hasil penelitian memberikan ketegasan bahwa pembelajaran pendidikan nilai dan moral termasuk pengembangan sikap toleransi dan kebersamaan di kalangan siswa lebih menghendaki penerapan model pembelajaran yang lebih banyak melibatkan siswa secara langsung dalam proses sosial dan pengamatan terhadap tingkah laku yang teramati.

\section{Penutup}

Pengembangan sikap toleransi dan kebersamaan di kalangan siswa menunju pada pembentukan kepribadian yang utuh, merupakan suatu dimensi penting dalam proses pendidikan. Dalam pelaksanaan pendidikan di sekolah pengembangan aspek-aspek ini seringkali tidak menjadi bagian yang utuh dalam proses pembelajaran. Sebagian besar guru lebih merasa bahwa misi pembelajarannya hanya mengembangkan aspek-aspek intelektual, dan sebagian lagi merasa hanya mempunyai tanggung jawab dalam pengembangan aspek-aspek ketrampilan siswa. Padahal sesungguhnya dalam semua mata pelajaran terkandung kewajiban untuk mengembangkan aspek-nilai dan sikap. Memang diakui bahwa ada beberapa mata pelajaran yang muatan pengembangan aspek nilai memiliki bobot lebih besar dari mata pelajaran-mata pelajaran lainnya.

Khusus dalam beberapa mata pelajaran yang lebih sarat dengan pendidikan nilai, maka upaya pengembangan sikap toleransi dan kebersamaan di kalangan siswa harus dapat dikembangkan melalui modelmodel pembelajaran yang lebih banyak menempatkan siswa sebagai partisipan yang aktif, baik dalam mengamati fenomena sosial yang terjadi dalam masyarakat maupun dalam melakukan suatu simulasi di kelas. Bentuk-bentuk pembelajaran yang melibatkan siswa secara langsung seperti ini oleh para ahli serta hasil-hasil penelitian dari berbagai pihak diyakini lebih mampu menumbuhkan kepekaan mereka terhadap nilainilai yang ingin dikembangkan antara lain sikap toleransi dan kebersamaan.

Dalam pengembangan sikap toleransi dan kebersamaan di kalnagan siswa, maka rekayasa pedagogis guru dalam proses pembelajaran menjadi sangat penting, karena guru memiliki kewenangan yang sangat besar dalam menentukan bentuk-bentuk pembelajaran yang diinginkan. Untuk itu guru dapat memilih model-model pembelajaran yang disaranka untuk pengembangan sikap siswa, sehingga siswa benarbenar memperoleh kesempatan yang luas dan nyata dalam kegiatan belajarnya. 


\section{DAFTAR PUSTAKA}

Alquranulkarim.

Banks A. James. (1997). Educatting Citizen in a Multicultural Society.

America: Teachers College Columbia University New York and London.

Dewantara, K.H. (1977). Karya Ki Hadjar Dewantara. Yogyakarta: Majelis Luhur Persatuan Taman Siswa.

Duska Ronald, Whelan Marielen. (1997). Moral Development, Aguide to Piaget and Kohlberg. Newyork: Gill and Macmillan.

England, Joan T. (1992). Pluralisme and Education:Its Meaning and Method. (online). Tersedia: http://www.ed.gov/database/ ERIC Digest/ede347494.htn (Desember 1992).

Garis-garis Besar Haluan Negara (GBHN) 1999-2004, TAP MPR No. IV/MPR/1999: Sinar Grafika

Haricahyono Cheppy. (1995). Dimensi-dimensi Pendidikan Moral. Semarang: IKIP Semarang Press.

Keller, M., Reuss, S. (1985). The Process of Moral Decission Making Normative and Emperical Conditions of Participation in Moral Discourse. Dalam M. Brkowitz \& Fritz K. Oser. Moral Education Theory and Aplication. Hillsdale, NJ: Erlbaum.

Sumaatmadja, N. (1990). Konsep dan Eksistensi Pendidikan Umum.

Program Pascasarjana: IKIP Bandung

Shihab, Q, H.M. (2001). Pendidikan Agama, Etika dan Moral. Mimbar

Pendidikan, Jurnal Pendidikan No. 1 tahun XX 2001 (19-23).

Tilaar, H.A.R. (1999). Pendidikan, Kebudayaan dan Masyarakat Madani

Indonesia. Strategi Reformasi Pendidikan Nasional. Bandung: PT

Remaja Rosdakarya Bandung.

Saripuddin, U. W. (1989). Konsep dan Strategi Pendidikan Moral Pancasila di Sekolah memengah (Suatu Penelitian Kepustakaan). Jakarta: Depdikbud Dirjen Dikti.

Tirtarahardja, U. (1994). Pengantar Pendidikan. Jakarta: Dirjen Dikti Depdikbud.

UNESCO-APNIEVE. (2000). Belajar Untuk Hidup Bersama dalam Damai dan Harmoni. Kantor Prinsipal Uniesco untuk Kawasan Asia Pasifik, Bangkok \& Universitas Pendidikan Indonesia.

Weil, My and Jocye, B. (1986). Models of Teaching. New York: Holt Rineart \& Winson. 